\title{
The Beloveža Formation of the Rača Unit in the Beskid Niski Mts. (Magura Nappe, Polish Flysch Carpathians) and adjacent parts of Slovakia and their equivalents in the western part of the Magura Nappe; remarks on the Beloveža Formation - Hieroglyphic Beds controversy
}

\author{
Jan GOLONKA and Anna WAŚKOWSKA
}

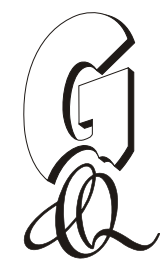

\begin{abstract}
Golonka J. and Waśkowska A. (2012) - The Beloveža Formation of the Rača Unit in the Beskid Niski Mts. (Magura Nappe, Polish Flysch Carpathians) and adjacent parts of Slovakia and their equivalents in the western part of the Magura Nappe; remarks on the Beloveža Formation - Hieroglyphic Beds controversy. Geol. Quart., 56 (4): 821-832, doi: 10.7306/gq. 1057

Eocene thin-bedded flysch, widespread in the Alpine Tethys ocean, is present within the Magura Nappe, the largest Outer Carpathian unit in Poland and Slovakia. Thin-bedded flysch sedimentation accompanied by hemipelagic shales took place accross the entire Magura Basin during Eocene times. The lithostratigraphic position of these deposits has been a subject of considerable discussion. Different names, such as the Hieroglyphic Beds, Hieroglyphic Formation, Łabowa Shale Formation, Grzechynia Sandstones and Beloveža Beds, Beloveža Formation have been used in the Outer Carpathians literature. We show a striking resemblance of the Beloveža Beds (Formation) from its type locality to the Hieroglyphic Beds from the Beskid Wysoki area and to typical Beloveža Beds from the Hańczowa Mts. We propose to the name Beloveža Formation should be applied to thin-bedded flysch within both Bystrica and Rača units of Magura Nappe and the name Hieroglyphic Formation should be restricted to the Skole Unit. The original type locality in Beloveža near Bardejov in Slovakia is selected as type section of the Beloveža Formation.
\end{abstract}

Jan Golonka and Anna Waśkowska, Faculty of Geology, Geophysics and Environmental Protection, AGH University of Science and Technology, Mickiewicza 30,30-059 Kraków, Poland, e-mails: jgolonka@agh.edu.pl; waskowsk@agh.edu.pl (received: March 28, 2012; accepted: September 20, 2012; first published online: November 30, 2012).

Key words: Outer Carpathians, Eocene, Magura Nappe, Rača Unit, Beloveža Formation, lithostratigraphy.

\section{INTRODUCTION}

The Magura Basin was formed in the Middle Jurassic as part of the Alpine Tethys (Golonka et al., 2006; Ślączka et al., 2006; Golonka, 2011). Deep-water sedimentation of radiolarites and carbonates dominated initially, then from the Late Cretaceous flysch sedimentation prevailed that included the characteristic thin-bedded flysch of the Ropianka and Beloveža type, proximal thick-bedded sandstones of the Magura Formation and hemipelagic red shales. Eocene thin-bedded flysch sedimentation accompanied by hemipelagic shales took place across the entire Magura Basin. Since the second half of the 19th century these deposits have been studied by many scientists from the Austro-Hungarian monarchy and subsequently from Poland, the Czech Republic and Slovakia (e.g., Paul, 1869; Uhlig, 1888; Świdziński, 1947; Ksią kiewicz, 1948, 1966; Matějka and Roth, 1956; Bieda, 1966; Geroch et al., 1967; Mahel' et al., 1968; Węcławik, 1969;
Sikora, 1971; Bogacz et al., 1979; Nemčok, 1990a, b; Oszczypko, 1991; Oszczypko et al., 2005; Ślączka et al., 2006; Waśkowska and Golonka, 2010 and references therein). Since 1869 they have been known as the Beloveža Beds (recently the Beloveža Formation; e.g., Nemčok, 1990a, b). Paul (1869) described these deposits at Beloveža near Bardejov (Fig. 1) placed now in Slovakia. Paul's classic expousure still exists and is available for detailed studies. It is located on southern side of the road from Bardejov to Beloveža, near Beloveža itself. One of the authors (J. Golonka) visited this exposure forty years ago with the late Jan Nemčok and Tomáš Koráb, who said that the object was known to many Slovak geologists and had remained unchanged since Paul's time. This exposure was recently revisited and documented. It belongs to the Magura Nappe, Rača Unit (e.g., Matějka and Roth, 1956; Mahel' et al., 1968; Nemčok, 1990a, b and references therein) and is shown in Figure 1. Outcrops of the Beloveža Formation are abundant in the Hańczowa Mts., the western part of Beskid Niski mountain range. We have studied these outcrops and compared 


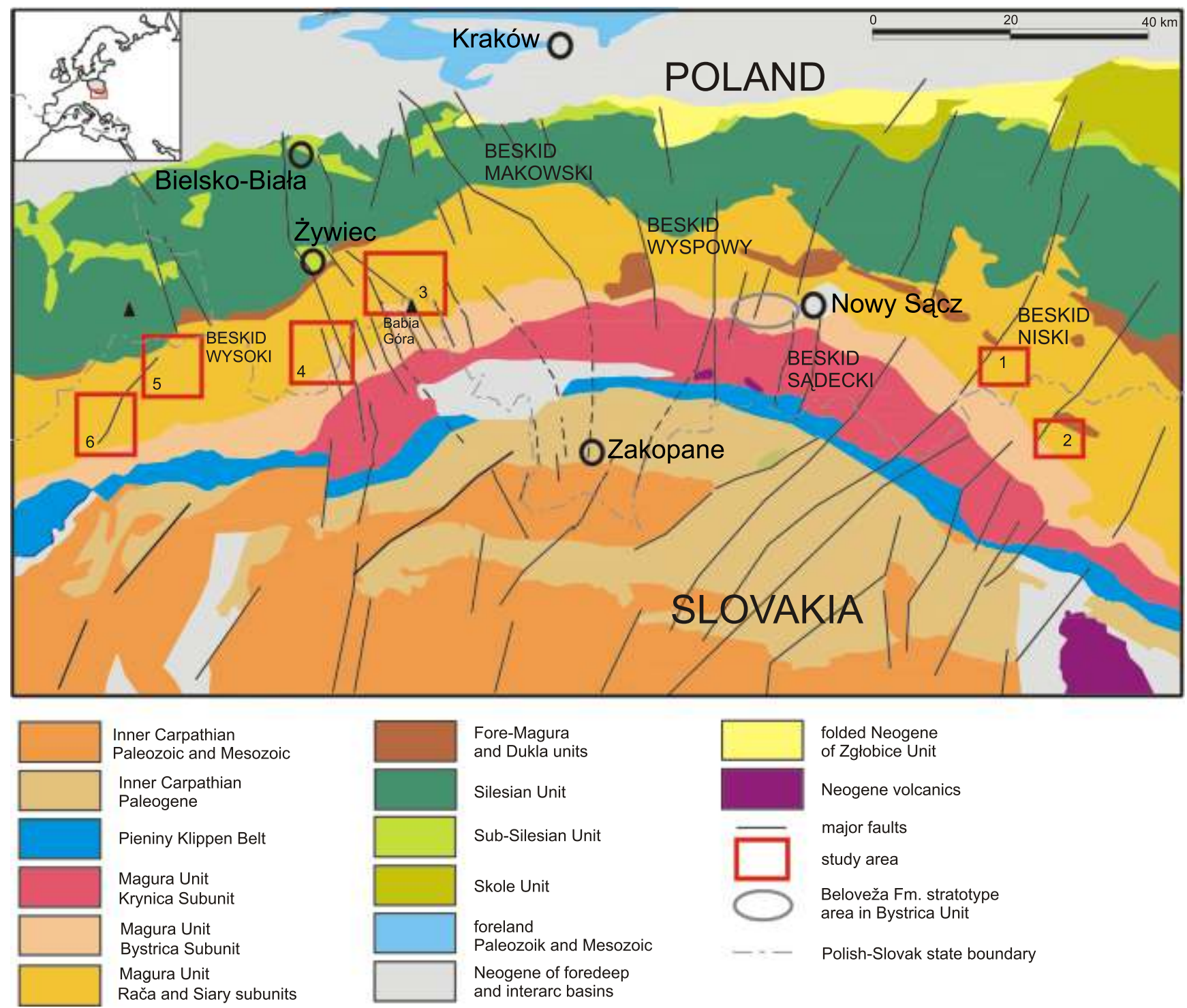

Fig. 1. The geological map of the West Carpathians and adjacent areas with location of the study areas

1 - Hańczowa Mts., with profiles Klimkówka Lake (Fig. 3), Stara Huta, Ropki, Skwirtne, Blechnarka; 2 - Beloveža area with stratotype profiles; 3 - Beskid Wysoki (Babia Góra) area, with profile Zawoja (Fig. 3); 4 - Beskid Wysoki (Pilsko) area, contains profile Jeleśnia (Fig. 3); 5 - Beskid Wysoki (Milówka) area, with profile Milówka (Fig. 3); 6 - Beskid Wysoki (Wielka Racza) area, with profile Ujsoły (Fig. 3) (after Golonka et al., 2005, modified)

them with other Rača Unit localities, where identical deposits are known as the Hieroglyphic Beds (Fig. 1). Here, we describe their lithology and lithostratigraphic position, micropalaeontological assemblages within Beloveža Formation and deposits assigned previously to the Hieroglyphic Beds within the Rača Unit. We propose a unified stratigraphic scheme of the Magura Paleogene strata in the western and eastern part of the Outer Carpathians in Poland and Slovakia.

\section{BELOVEŽA FORMATION IN THE HAŃCZOWA MTS.}

\section{LITHOLOGY}

A synthetic profile of the deposits of the Rača Unit in the Hańczowa Mts. in the Uście Gorlickie-Wysowa area (Figs. 1 and 2) is depicted in Figure 3. The Upper Cretaceous-Paleocene Ropianka Formation is overlain by variegated shales of the Łabowa Shale Formation followed by the Beloveža Formation and the Magura Formation (Fig. 4). According to Węcławik (1969) the Beloveža Formation starts just above the last red shale unit of the Łabowa Shale Formation. It is represented by thin-bedded typical flysch with shale dominant (Fig. 5). The typical sandstones are fine-grained gray, blue-gray, steel-gray, siliceous with abundant "hieroglyphs", mainly biogenic in origin and representing different trace fossil taxa. They commonly display lamination, however due to their siliceous cement and dense joining they disintegrate into prismatic blocks, not plates. Shales are gray, green-gray, green-blue olive green in colour, with a predominance of clay and with small amounts of carbonates. These features are characteristic of the innermost part of the Rača Unit. The upper 


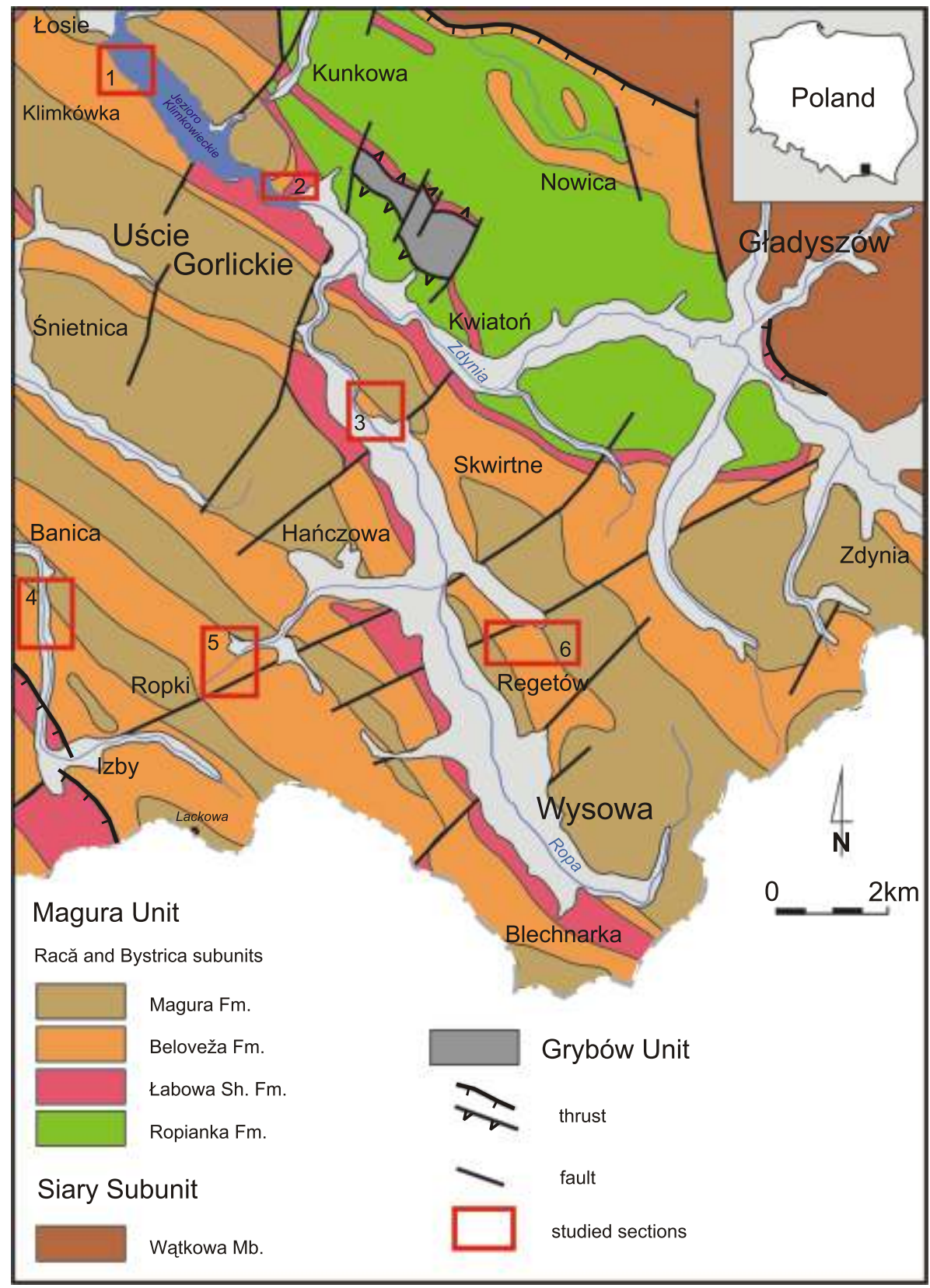

Fig. 2. The geological map of the Uście Gorlickie-Wysowa area (after Rączkowski et al., 1992, modified)

Sections studied: 1 - Klimkówka Lake, 2 - Uście Gorlickie, 3 - Hańczowa, 4 - Banica, 5 - Ropki, 6 - Regetów

boundary is marked by the first thick sandstone of the Magura Formation. Many varieties of sandstones and shales can be distinguished within the Beloveža Formation as mapped across the entire Hańczowa Mts. region (see Fig. 4). The shales are locally dark with an abundant argillaceous component, while 1-2 metre thick variegated intercalations are present, particularly in the northern part of the region. They occur at different levels of the Beloveža Formation and are usually of short lateral extent. Thicker intercalations of sandstones are also present, especially in the uppermost part of the formation. The number and thickness of sandy intercalations increases in the upper part, as the calcareous component decreases (Sikora, 1971).

\section{BIOSTRATIGRAPHY}

Foraminiferal assemblages from the Beloveža Fm. are usually taxonomically poor, cosmopolitan, long-life agglutinated forms with dwarf specimens dominant. The typical Eocene foraminifera present within assemblages from the Beloveža Fm. are represented by: Eratidus gerochi Kaminski et Gradstein, Pseudonodosinella elongata (Grzybowski), Praesphaerammina subgaleata (Vašiček), Reticulophragmium amplectens (Grzybowski). There are individual specimens of Ammodiscus latus Grzybowski as well as Chilostomella chilostomelloides Vašiček. These have been found in 

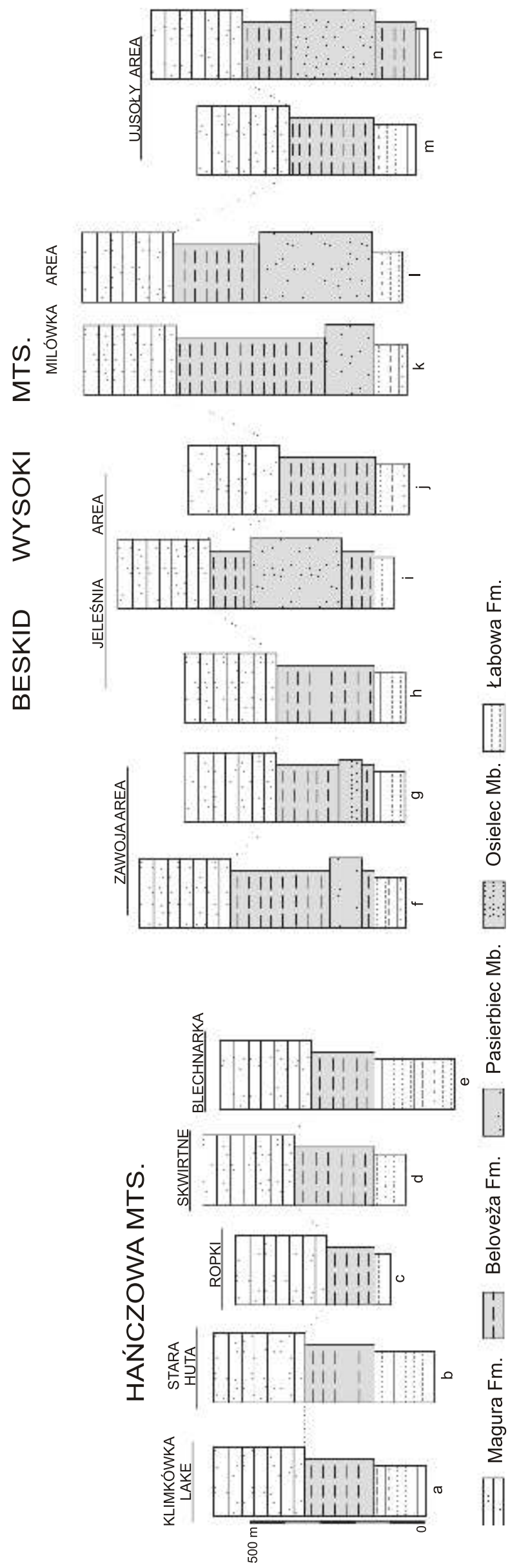

the pelitic deposits (usually in variegated intercalations). Assemblages with Haplophragmoides parvulus Blaicher and Haplophragmoides nauticus Kender, Kaminski \& Jones are common. These indicate a latest Middle Eocene-early Late Eocene age. Haplophragmoides parvulus Blaicher, noted from the Eocene of the Outer Carpathians Basins as a good biostratigraphical marker indicates a late Eocene (e.g., Blaicher, 1961; Olszewska et al., 1996; Olszewska, 1997; Golonka and Waśkowska, 2011b and references therein; Fig. 6). Preliminary study of Haplophragmoides nauticus Kender et al. suggests it is widespread and important biostratigraphically in Eocene deposits of the Carpathians (Waśkowska-Oliwa, 2008).

Monospecific associations of Praesphaerammina subgaleata (Vašiček) as well as associations dominated by Bathisiphon-Recurvoides or Bathisiphon-Trochammina-Haplophragmoides characterize the Beloveža Foramation deposits. Assemblages with numerous Reticulophragmium amplectens (Grzybowski) occur in the lower part of this formation suggesting a Lutenian age. Mass occurrences of Praesphaerammina subgaleata (Vašiček) are typical, especially of the upper part of the Beloveža Formation, associated with the upper part of the Reticulophragmium amplectens zone and the lower part of the Ammodiscus latus zone (Middle Eocene); the biozones are after Olszewska (1997; see also Golonka and Waśkowska, 2011a). Węcławik (1969) and Sikora (1971) determined a Middle Eocene age for the Beloveža Formation at different localities in the Beskid Niski Mts.

Samples collected for foraminifera study from the uppermost part of the Klimkówka Lake profile represent assemblages rich in Praesphaerammina subgaleata (Vašiček) with occurrences of Ammodiscus latus Grzybowski, indicating a Bartonian age. The Magura Sandstones overlying the Beloveža Formation in this profile contain calcareous nannoplankton belonging to NP 17/18 Zone, indicating the latest Middle Eocene and earliest Late Eocene (Oszczypko et al., 2011). Latest Middle Eocene monospecific associations of Praesphaerammina subgaleata (Vašiček) were determined from samples taken from the type locality at Beloveža. Hanzlíková (in Machel’ et al., 1968) also quoted poor microfaunal assemblages indicating a similar age (assemblages with Praesphaerammina subgaleata (Vašiček) and Chillostomelloides ovicula Nuttall).

\section{BELOVEŽA FORMATION (HIEROGLYPHIC BEDS) IN THE BESKID WYSOKI MTS.}

\section{LITHOLOGY}

The lithostratigraphic inventory of the Eocene deposits in the Magura-Rača Unit from the Zawoja area (Beskid Wysoki Mts., see Fig. 1) is represented by variegated shales of the Łabowa Formation, which pass 


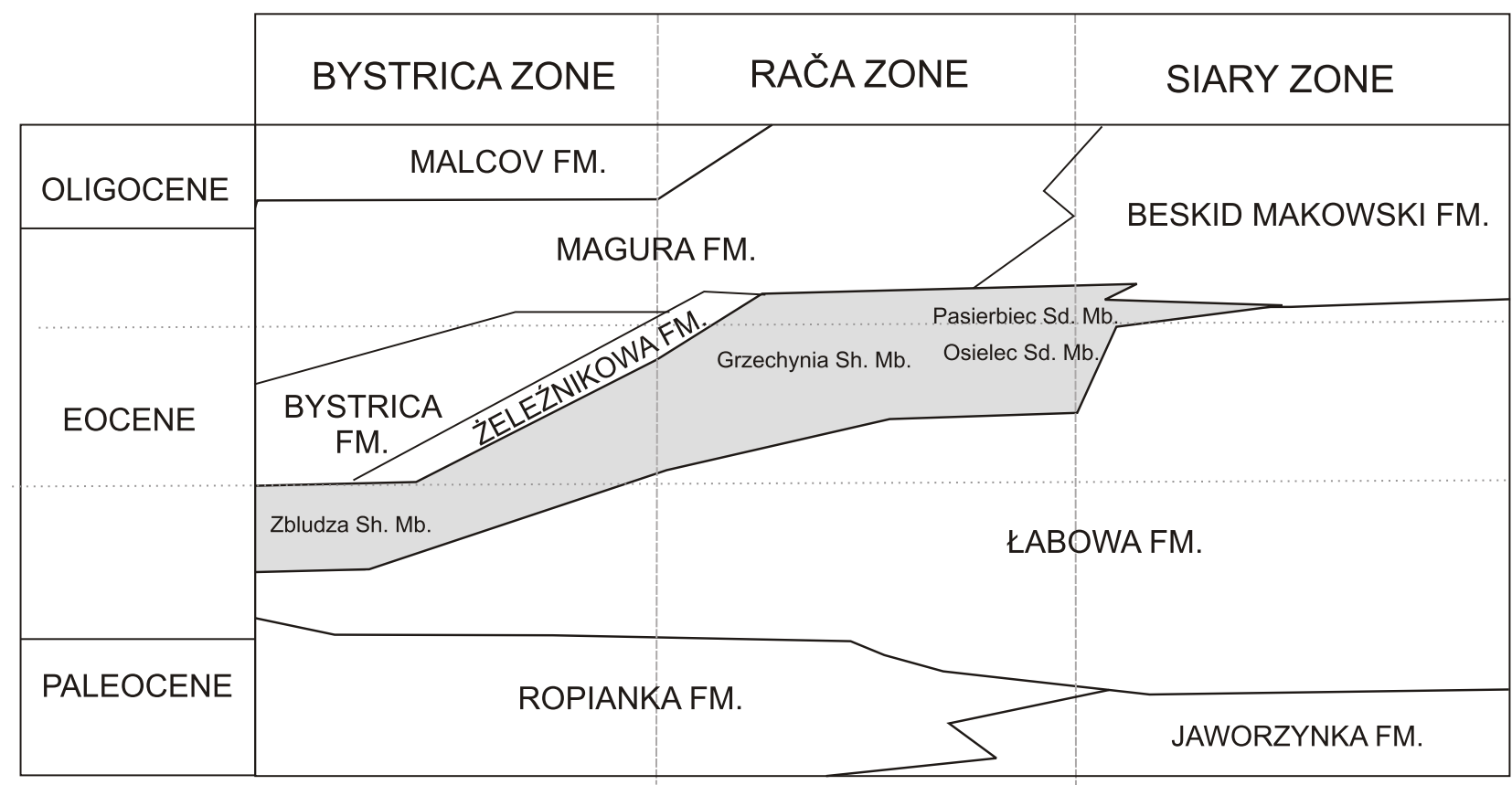

BELOVEŽA FM.

Fig. 4. Stratigraphical scheme of Paleogene deposits of the Rača and neighbouring units in the Magura Nappe

upwards into thin-bedded turbidites of the Middle Eocene Beloveža Formation (Hieroglyphic Beds of Ksią kiewicz, 1948) with packages of thick-bedded sandy strata located in the lower part of the formation. These packages belong to the Pasierbiec and Osielec sandstones and are widespread only in the Beskid Wysoki (Figs. 1 and 3), Wyspowy and Makowski Mts. (Fig. 1). The Beloveža Formation is overlain by thick-bedded sandstones with intercalations of the thin turbidites of the Magura Formation (Ksią kiewicz, 1966; Geroch et al., 1967; Ksią kiewicz, 1971a, b; Golonka and Wójcik, 1978 a, b; Ryłko et al., 1993; Malata et al., 1996; Ryłko, 2004; Golonka and Waśkowska, 2011a and references therein). This clearly starts with first thick-bedded sandy unit. The lithological sequence of Eocene thin-bedded flysch of Beloveža Formation is very similar to deposits described from Beskid Niski Mts. The thin- to thick-bedded shaly complexes are interbedded with thin- or medium-bedded sandstones (Fig. 7). Shale units contain mudstones and thin claystones that are grey-green and olive in colour. The sandstones are hard, cemented by a siliceous-carbonate matrix gray in colour and usually with parallel lamination. They disintegrate into small blocks. The numerous "hieroglyphs" (mechano- and bioglyphs) occur on their bottom planes. The flutecasts indicate transport of the clastic material generally from the east (Ksią kiewicz, 1966, 1971a, b).

\section{BIOSTRATIGRAPHY}

Foraminiferal assemblages are poor and of low taxonomically diversity. Monospecific assemblages with Praesphaerammina subgaleata (Vašiček) are common. Characteristic Eocene taxa such as Pseudonodosinella elongata (Grzy- bowski) and Chilostomella chilostomelloides Vašiček are present. Assemblages with Reticulophragmium amplectens (Grzybowski) were noticed here and they underlie deposits with Praesphaerammina subgaleata (Vašiček) (Ksią kiewicz, 1971a, b; Golonka and Wójcik 1978a, b; Malata, 1981; Malata et al., 1996; Golonka and Waśkowska, 2011a and references therein). The composition as well as the structure of the foraminiferal assemblages resemble those from the Beloveža Formation of the Hańczowa Mts. This microfauna indicates Middle/earliest Late Eocene age.

\section{BELOVEŽA FORMATION - HIEROGLYPHIC BEDS CONTROVERSY}

Paul (1869) recognized the Beloveža Beds at Beloveža near Bardejov in Slovakia (Fig. 1). He included variegated shales and thin-bedded flysch into this unit. Later Uhlig (1889) separated thin-bedded flysch of the Beloveža Beds from a unit of variegated shales (now the Łabowa Formation). This division was commonly applied in the lithostratigraphy of the Magura Nappe in Poland (e.g., Świdziński, 1947; Węcławik, 1969; Bogacz et al., 1979; Malata et al., 1988; Waśkowska and Golonka, 2010) and the name Beloveža Beds was used for the characteristic shaly-sandstone Eocene deposits between variegated shales of the Łabowa Formation and thick-bedded sandstones of the Magura Formation in the Beskid Niski and Sądecki region. A different approch was taken by Slovak geologists. They include the variegated shales (Łabowa Formation in Poland) within the Beloveža Beds (e.g., Mahel' et al., 1968; Leško and Samuel, 1983; Nemčok, 1990a, b; Polák et al., 2002). They also restrict the term 

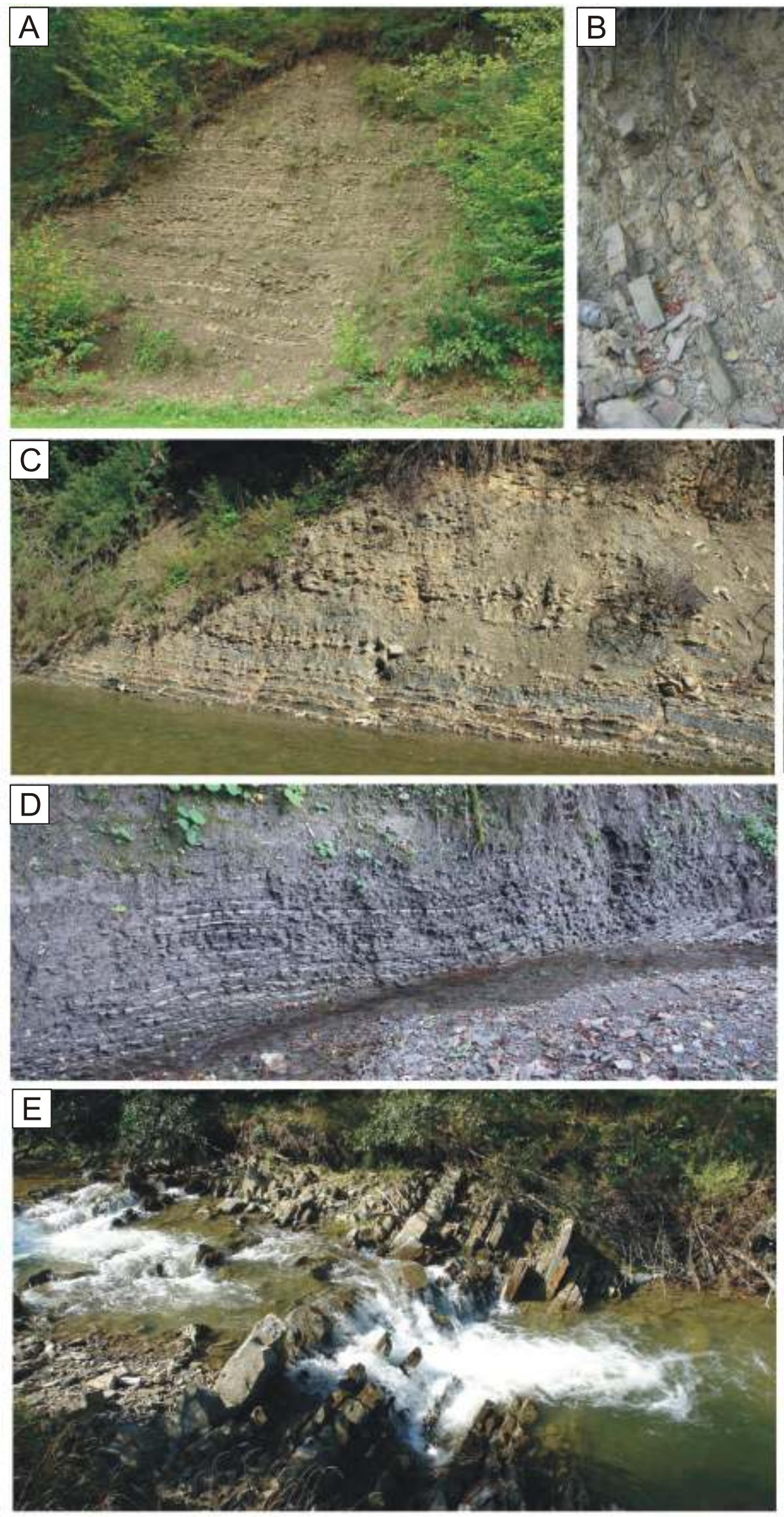
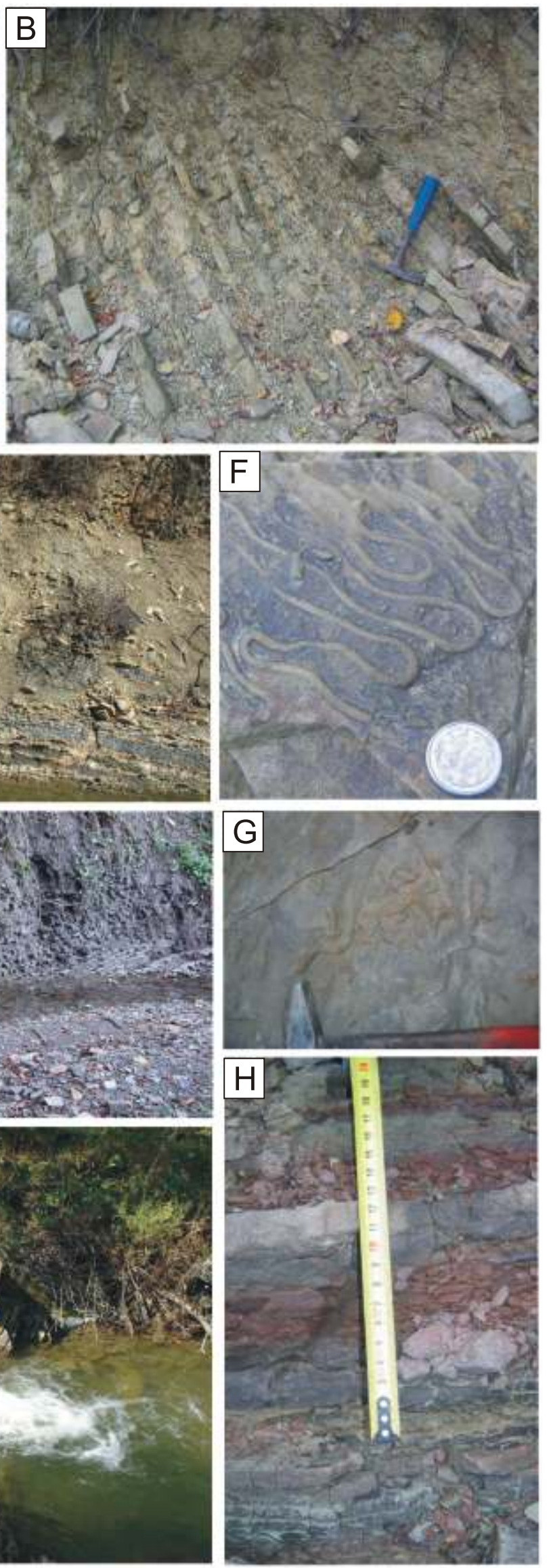

Fig. 5. Beloveža Fm. in Beloveža-Hańczowa Mts. region

A - Beloveža (type section), height of picture 15 m; B - Klimkówka Lake; C - Hańczowa (Ropa River valley), height of picture 10 m; D - Ropki (Ropka Stream valley), height of picture $5 \mathrm{~m} ; \mathbf{E}$ - Izby (Biała River valley - the waterfall is at the boundary between the Beloveža Fm. and the Poprad Sandstone Mb.), height of picture $5 \mathrm{~m} ; \mathbf{F}, \mathbf{G}$ - bioglyphs (Klimkówka Lake section); $\mathbf{H}$ - variegated shale intercalations in the upper part of Beloveža Fm. (Klimkówka Lake section) 


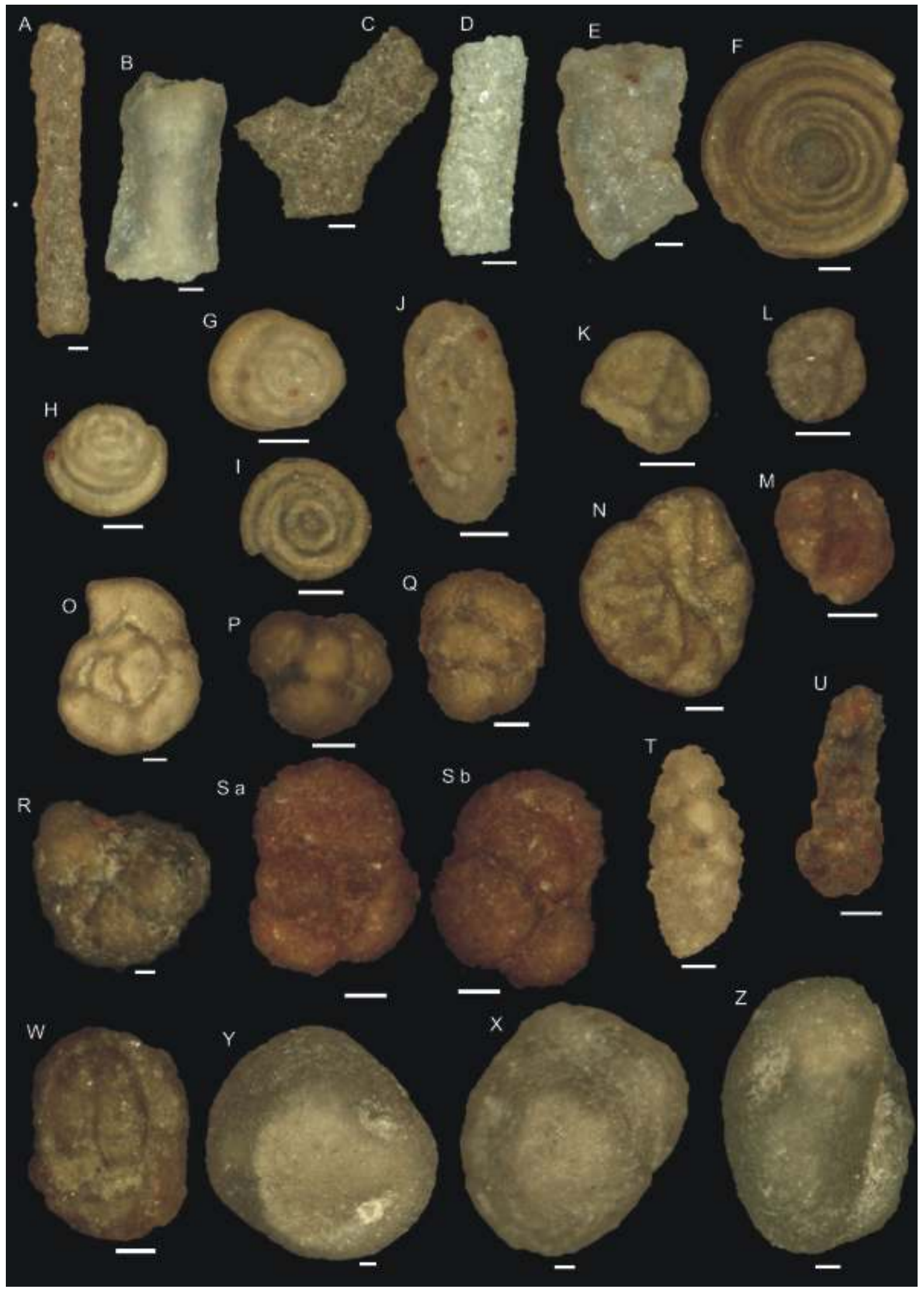

Fig. 6. Microscope images of foraminifera from the Wysowa-Uście Gorlickie area

A - Psammosiphonella cylindrica (Glaessner); B, E - Bathysiphon sp.; C, D - Nothia excelsa (Grzybowski); F - Ammodiscus tenuissimus Grzybowski; G, H - Glomospira charoides (Jones et Parker); I - Glomospira gordialis (Jones et Parker); J - Ammodiscus peruvianus Berry; K-M Haplophragmoides parvulus Bleicher; $\mathbf{N}$ - Haplophragmoides walteri (Grzybowski); O-Trochamminoides cf. dubius (Grzybowski); P, R - Recurvoides walteri (Grzybowski); S - Trochammnina sp.; T - Karrerulina conversa (Grzybowski); U - Eratidus gerochi Kaminski et Gradstein; W Paratrochamminoides gorayskii (Grzybowski); X-Z - Praesphaerammina subgaleata (Vašiček); scale bar - $100 \mu \mathrm{m}$ 

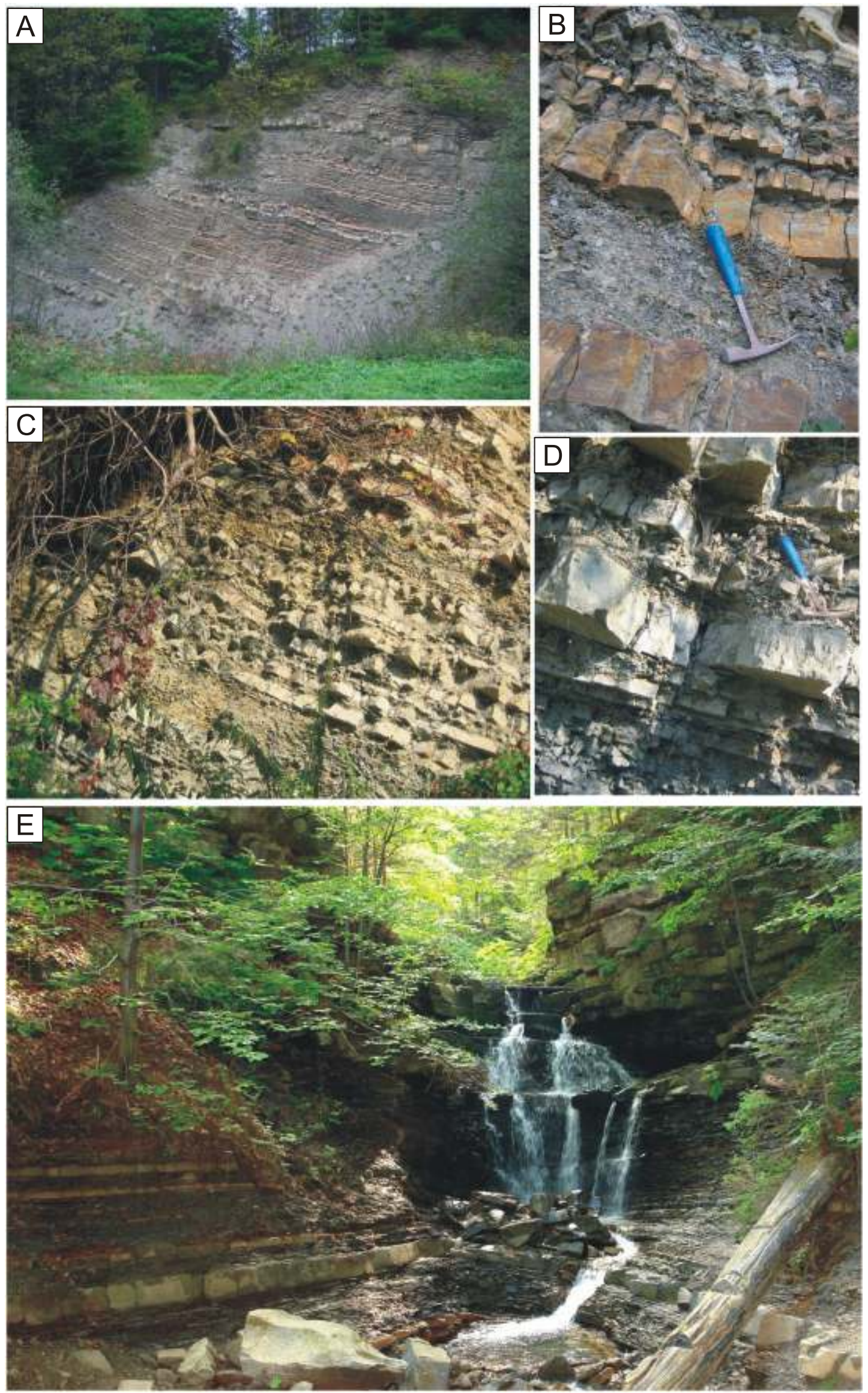

Fig. 7. The Beloveža Fm. in the Beskid Wysoki and Beskid Makowski regions

A, B - Wilczna (Beskid Wysoki); C, D - Łętownia (Beskid Makowski region); E - Zawoja-Mosorny Stream (Beskid Wysoki region); A - height of picture $25 \mathrm{~m}, \mathrm{C}$ - height of picture $10 \mathrm{~m}$ 


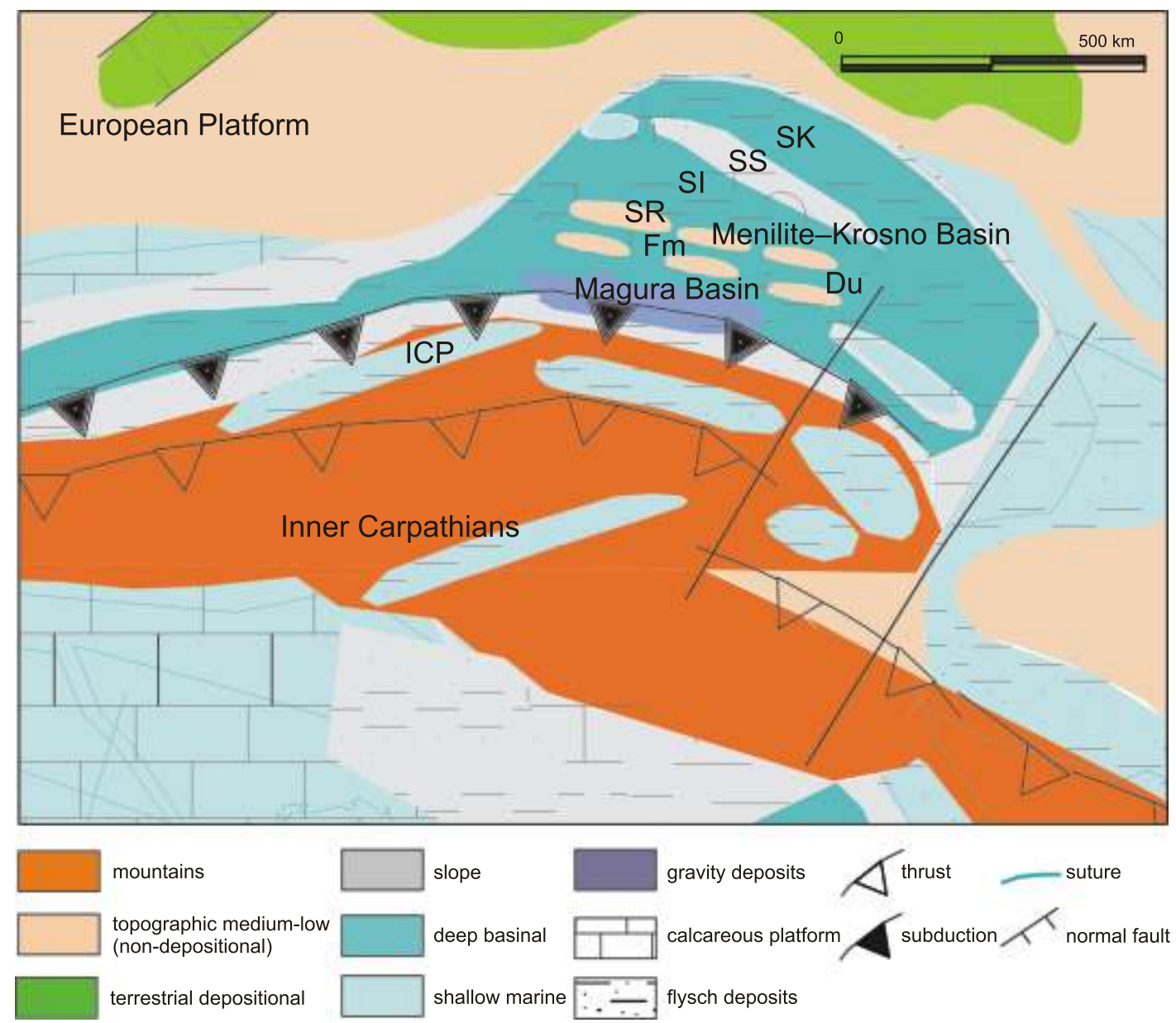

Fig. 8. Paleogeography of the Outer Carpathian basins during the Late Eocene-earliest Oligocene

Du - Dukla, Fm - Fore-Magura Basin, ICP - Inner Carpathian Paleogene, SI - Silesian Basin, SK - Skole Basin, SR - Silesian Ridge, SS - Sub-Silesian sedimentary area from Golonka (2011), modified

Magura Formation to the Krynica Unit, applying different names such as Kycera Sandstone or Makovica Sandstone. Potfaj (2003, sea also Potfaj et al., 2002) attempted to subdivide the Beloveža Formation in the Kysuca region south-west of the Beskid Wysoki Mts., using provisional terms such as "Beloveža beds of Bystrica provenance".

Simultaneously, in the Rača Unit in the more western area of the Beskid Wysoki Mts. the name Hieroglyphic Beds was used after Ksią kiewicz (1948) who first applied this name to Eocene thin-bedded flysch deposits in the Magura Nappe north of the Babia Góra area. The term Hieroglyphic Beds, however, has existed in the lithostratigraphical nomenclature of the Outer Carpathians since 1879 when Paul and Tietze (1879) distinguished thin-bedded flysch within the Skole Nappe profile (see Fig. 1). The Hieroglyphic Beds in the Beskid Wysoki area (Sikora and ytko, 1959; ytko, 1962; Bieda, 1966; Jednorowska, 1966; Ksią kiewicz, 1966; Golonka and Wójcik, 1978a, b; Golonka, 1981; Malata, 1981; Ryłko, 1992) are similar to the Beloveža Beds in the Beskid Niski area both in lithological composition and in their position within the Magura Basin profile. A term with a geographical element - the Grzechynia Hieroglyphic sandstones or formation (Golonka and Wójcik, 1978a, b; Wójcik et al., 1996) - has also been used. The name Hieroglyphic Beds was later also introduced into the
Beskid Niski area (Sikora, 1971; Rączkowski et al., 1992; Węcławik and Wójcik, 1995). The term Hieroglyphic Beds is still in use within the Rača Unit in the Polish Carpathians (e.g., Malata et al., 1996; Ryłko, 2004; Ślączka et al., 2006; Leszczyński, 2008). The Beloveža Beds sandstones sensu Ksią kiewicz (1966) contain more carbonate cement and disintegrate into plates. A siliceous cement is characteristic of the Hieroglyphic Beds sandstones. This feature, together with a dense network of joints, causes blocky, prismatic disintegration of the sandstones. The colour of shales within the Beloveža Beds in the Bystrica unit south of Babia Góra is brighter within gray, green-gray, green-blue olive green varieties. The Czech and Slovak geologists applied the name Beloveža Beds to the undivided red (variegated) shales and thin-bedded flysch within the entire Magura Unit (e.g., Matejka and Roth, 1956; Mahel' et al., 1968 and references therein).

Currently the name Beloveža Formation is in use for the Bystrica Unit (Fig. 1). Oszczypko (1991) formalized the lithostratigraphy for this unit and provided reference sections in the Zbludza and eleźnikowski streams (located within the oval in Fig. 1). Later he assigned the Hieroglyphic Beds sensu Ksią kiewicz (1966) in the Rača Unit to the Beloveža Formation without new type localities or in-depth discussion (see Oszczypko, 2002; Oszczypko et al., 2002, 2005; Oszczypko in Wagner, 2008). 
The age of the Beloveža Formation of the Rača Unit is still subject to discussion. The Middle Eocene (Lutetian-Bartonian) to earliest Late Eocene age was determined on the basis of foraminiferal assemblages (Sikora and ytko, 1959; Bieda, 1966; Geroch et al., 1967; Ksią kiewicz, 1971a, b; Sikora, 1971; Malata, 1981; Wójcik, 1992; Golonka and Waśkowska, 2011a and references therein). In the Lubomierz section (located within the oval in Fig. 1), the lowermost part of the profile was assigned to the Early Eocene using agglutinated foraminifera, but nannoplankton assemblages are representative of the Middle Eocene-Lutetian (Oszczypko et al., 2005). The late Middle Eocene (Lutetian) to Late Eocene (Prabonian) interval was also indicated (Oszczypko, 1992; Wagner, 2008).

The Beloveža Beds (Formation) from Paul's (1869) type locality displays striking resemblance to the typical Hieroglyphic Beds from the Zawoja area in the Beskid Wysoki area (Fig. 7) and to typical Beloveža Beds from the Hańczowa Mts. (Fig. 5). Their lithology, stratigraphical position, sedimentary environment, age, fossils and location within the Magura Basin are very similar. Lateral variations e.g., occurrences of thin variegated shales, intercalations of sandy units (Osielec, Pasierbiec members) or variations in silica content reflect differences within the local sedimentary environment of the Magura Basin. By contrast, the Beloveža Formation at its type locality and in the reference section in the Zbludza Stream (Oszczypko, 1991) and at other localities in the Bystrica Unit display differences in lithology, stratigraphic position and location within the Magura Basin. The name Beloveža Formation may be still applicable here, but requires redefinition.

The systematic arrangement of the lithostratigraphic units according to their occurrence within the original basins and in other sedimentary areas will lead to the unification of these units across the West Carpathians flysch outcrops in Poland, the Czech Republic and Slovakia (Golonka and Waśkowska-Oliwa, 2007). Palinspastic reconstructions (Golonka et al., 2000, 2006, 2011 and references therein) showing that sedimentation in the Carpathian basins took place within a few deep-water basins separated by ridges. The number of ridges and their positions changed through the Jurassic to Oligocene/Miocene. The Paleocene/Eocene was period of rebuilding of the Carpathian basins. As a result, two basins, the remnant Magura Basin and the external Menilite-Krosno (Silesian, Skole) Basin originated at the end of the Eocene (Fig. 8) and were fully developed during Oligocene times (Golonka et al., 2000; Ślączka et al., 2006; Golonka and Waśkowska-Oliwa, 2007; Golonka, 2011 and references therein). The Hieroglyphic Formation (Beds) of Paul and Tietze (1879) was deposited within the external basin. This formation represents thin-bedded Eocene flysch deposits rich in hieroglyphs deposited. The type locality is located within the Skole Nappe (see Paul and Tietze, 1879; Rajchel, 1990). Following priority, it is better to restrict the name Hieroglyphic Formation to the Skole Nappe in the Outer Carpathians and to redefine similar deposits in Silesian Nappe representing the same Menilite-Krosno Basin. The term Beloveža Formation should be applied to Eocene deposits of the Magura Basin (represented mostly in Magura Nappe), separate from the Menilite-Krosno sedimentary area.

\section{CONCLUSIONS}

We propose the following approach to the Hieroglyphic Beds, Hieroglyphic Formation, Łabowa Shale Formation, Beloveža Beds and Beloveža Formation:

- to apply name Łabowa Shale Formation to a mappable continuous Paleocene-Lower/Middle Eocene variegated shale unit in the Magura Nappe;

- to apply name Beloveža Formation to thin-bedded flysch with in both Bystrica and Rača Units of the Magura Nappe;

- to use the original type locality of Paul (1869) at Beloveža near Bardejov (Slovakia) for the type section of the Beloveža Formation. Localities in Wilczna (Beskid Wysoki Mts.) and Uście Gorlickie (Beskid Niski Mts.) in Rača Unit should be used as reference sections;

- to establish new members within the Beloveža Formation; for example the Zbludza Shale Member for thin-bedded flysch in the Bystrica Unit, the Grzechynia Shale Member for the northern part of the Rača Unit; also for thick-bedded sandstone intercalations such as the Pasierbiec Sandstone Member and Osielec Sandstone Member;

- to restrict name Hieroglyphic Formation to the Skole Nappe in the Outer Carpathians and similar reworked deposits in the Silesian Nappe and other units connected with the early stages of the Menilite-Krosno Basin, that originated during Eocene times.

Acknowledgements. This research has been financially supported by AGH University of Science and Technology in Kraków grant no. 11.11.140.173.

\section{REFERENCES}

BIEDA F. (1966) - Du e otwornice z eocenu serii magurskiej okolic Babiej Góry. Przew. 39 Zjazdu Pol. Tow. Geol. Babia Góra, czerwiec, 1966: 60-70. Wyd. Geol., Warszawa.

BLAICHER J. (1961) - Zone with calcareous microfauna in the Upper Eocene of the Magura Series (Flysch Carpathians). Biul. Inst. Geol., 166: 5-59.

BOGACZ K., DZIEWAŃSKI J., JEDNOROWSKA A. and WĘCŁAWIK S. (1979) - Paleogene deposits of the Magura nappe near Owczary
(Polish Flysch Carpathians) (in Polish with English summary). Rocz. Pol. Tow. Geol., 59: 43-65.

GEROCH S., JEDNOROWSKA A., KSIA KIEWICZ M. and LISZKOWA J. (1967) - Stratigraphy based upon microfauna in the Western Polish Carpathians. Biul. Inst. Geol., 211: 185-282.

GOLONKA J. (1981) - Objaśnienia do Mapy geologicznej Polski, skala 1:200 000, ark. Bielsko-Biała. Inst. Geol. 
GOLONKA J. (2011) - Evolution of the Outer Carpathian Basins. Grzybowski Found. Spec. Publ., 17: 3-14.

GOLONKA J. and WAŚKOWSKA A. (2011a) - The Beloveža Formation of the Rača Unit, Magura Nappe, in the Beskid Wysoki Mts (Polish Outer Carpathians) north of Babia Góra Mountian - monospecific assemblages with Praespaerammina subgaleata (Vašiček). Grzybowski Found. Spec. Publ., 17: 27-35.

GOLONKA J. and WAŚKOWSKA A. (2011b) - The Zembrzyce Shale Member of the Beskid Makowski Formation in the Babica area (Siary Zone of the Magura Nappe, Polish Outer Carpathians); the Haplophragmoides parvulus Blaichet type locality. Grzybowski Found. Spec. Publ, 17: 27-35.

GOLONKA J. and WAŚKOWSKA-OLIWA A. (2007) - Stratigraphy of the Polish Flysch Carpathians between Bielsko-Biała and Nowy Targ. Kwart. AGH, Geologia, 33: 5-28.

GOLONKA J. and WÓJCIK A. (1978a) - Objaśnienia do Szczegółowej mapy geologicznej Polski, skala 1:50 000, ark. Jeleśnia. Inst. Geol.

GOLONKA J. and WÓJCIK A. (1978b) - Szczegółowa mapa geologiczna Polski, skala 1: 50 000, ark. Jeleśnia. Instytut Geologiczny.

GOLONKA J., OSZCZYPKO N. and ŚLACZZKA A. (2000) - Late Carboniferous Neogene geodynamics and paleogeography of the circum-Carpathian region and adjacent area. Ann. Soc. Geol. Pol., 70: 107-136.

GOLONKA J., ALEKSANDROWSKI P., AUBRECHT R., CHOWANIEC J., CHRUSTEK M., CIESZKOWSKI M., FLOREK R., GAWEDA A., JAROSIŃSKI M., KĘPIŃSKA B., KROBICKI M., LEFELD J., LEWANDOWSKI M., MARKO F., MICHALIK M., OSZCZYPKO N., PICHA F., POTFAJ M., SŁABY E., ŚLĄCZKA A., STEFANIUK M., UCHMAN A. and ELAŹNIEWICZ A. (2005) - The Orava Deep Drilling Project and post-Palaeogene tectonics of the Northern Carpathians. Ann. Soc. Geol. Pol., 75: 211-248.

GOLONKA J., GAHAGAN L., KROBICKI M., MARKO F., OSZCZYPKO N. and SLACZKA A. (2006) - Plate Tectonic Evolution and Paleogeography of the Circum-Carpathian Region. AAPG Mem., 84: 11-46.

JEDNOROWSKA A. (1966) - Zespoły małych otwornic w warstwach jednostki magurskiej rejonu Babiej Góry i ich znaczenie stratygraficzne. Przew. 39 Zjazdu Pol. Tow. Geol. Babia Góra, czerwiec, 1966: 71-100. Wyd. Geol., Warszawa.

KSIA KIEWICZ M. (1948) - Stratigraphy of the Magura series north of the Babia Góra, Western Carpathians (in Polish with English summary). Biul. Inst. Geol., 48: 1-34.

KSIA KIEWICZ M. (1966) - Geologia region babiogórskiego. Przew. 39 Zjazdu Pol. Tow. Geol. Babia Góra, czerwiec, 1966: 5-58. Wyd. Geol., Warszawa.

KSIA KIEWICZ M. (1971a) - Szczegółowa mapa geologiczna Polski, skala 1:50 000, ark. Zawoja. Inst. Geol.

KSIA KIEWICZ M. (1971b) - Objaśnienia do Szczegółowej mapy geologicznej Polski, skala 1:50 000, ark. Zawoja. Wyd. Geol., Warszawa.

LEŠKO B. and SAMUEL O. ( 1983) - Belovezskie vrstvy. Stratigraficky slovnik Zapadnych Karpat 1 A/K (ed. D. Andrusov): 122-123. Geologicky Ustav Dionyza Stura.

LESZCZYŃSKI S. (2008) - Outline of geology of southern Poland. Inchnological sites of Poland. In: The Holy Cross Mountains and the Carpathian Flysch (eds. G. Pieńkowski and A. Uchman): 93-98. Państw. Inst. Geol.

MAHEL' M., BUDAY T., CICHA I., FUSÁN O., HANZLÍKOVÁ E., CHMELÍK F., KAMENICKÝ J., KORÁB T., KUTHAN M., MATĚJKA A., NEMČOK J., PÍCHA F., ROTH Z., SENEŠ J., VAŚKOWSKÝ I. and ŽEBERA K. (1968) - Regional geology of Czechoslovakia. Part II, The West Carpathians. Geological Survey of Czechoslovakia, Publishing House of the Czechoslovak Academy of Sciences

MALATA E. (1981) - The stratigraphy of the Magura nappe in the western part of the Beskid Wysoki Mts., Poland, based on microfauna (in Polish with English summary). Biul. Inst. Geol., 331: 103-113.

MALATA E., OSZCZYPKO N. and WECŁAWIK S. (1988) - Stratygrafia osadów płaszczowiny magurskiej w rejonie Uścia Gorlickiego. Spraw. Pos. Kom. PAN o/Kraków, 32: 322-324.

MALATA E., MALATA T. and OSZCZYPKO N. (1996) - Litho- and biostratigraphy of the Magura Nappe in the eastern part of the Beskid
Wyspowy Range (Polish Western Carpathians). Ann. Soc. Geol. Pol., 66: 269-284.

MATĚJKA A. and ROTH Z. (1956) - Geologie magurského flyše v severním povodí Váhu mezi Bytčou a Trenčínem. Rozpravy. Ústř. Úst. Geol., 22: 1-22.

NEMČOK J. (1990a) - Regionalne Geologicke Mapy Slovenska 1:50 000. Geologicka Mapa Pienin, Čergova, L'ubovnianskej a Odnavskej Vrchoviny. Geologicki Ustaw Dionyza Stura.

NEMČOK J. (1990b) - Vysvetlivky ku Geologickej Mape Pienin, Čergova, L'ubovnianskej a Odnavskej Vrchoviny. Geologicky Ustav Dionyza Stura.

OLSZEWSKA B. (1997) - Foraminiferal biostratigraphy of the Polish Outer Carpathians: a record of basin geohistory. Ann. Soc. Geol. Pol., 67: 325-337.

OLSZEWSKA B., ODRZYWOLSKA-BIEŃKOWA E., GIEL M.D., PO ARYSKA K. and SZCZECHURA K. (1996) - Rząd Foraminiferida Eichwald, 1830. In: Budowa geologiczna Polski, III. Kenozoik. Trzeciorzęd. Paleogen, cz. 3a. Atlas skamieniałości przewodnich i charakterystycznych (eds. L. Malinowska and M. Piwocki): 45-215. Państw. Inst. Geol.

OSZCZYPKO N. (1991) - Stratigraphy of the Palaeogene deposits of the Bystrica Subunit (Magura Nappe, Polish Outer Carpathians). Bull. Pol. Acad. Sc., Earth Sc., 39: 415-433.

OSZCZYPKO N. (1992) - Evolution of the Magura Basin in Late Cretaceous and Paleogene (in Polish with English summary). Prz. Geol., 40: 397-404.

OSZCZYPKO N. (2002) - Late Cretaceous through Paleogene evolution of Magura Basin. Geol. Carpath., 43: 333-338.

OSZCZYPKO N., GOLONKA J., MALATA T., POPRAWA P., SŁOMKA T. and UCHMAN A. (2002) - Tectono-stratigraphic evolution of the Outer Carpathian basins (Western Carpathians, Poland). Geol. Carpath., 53, special issue CD, 8.

OSZCZYPKO N., MALATA E., BĄK K., KĘDZIERSKI M. and OSZCZYPKO-CLOWES M. (2005) - Lithostratigraphy and biostratigraphy of the Upper Albian-Lower/Middle Eocene flysch deposits in the Bystrica and Rača subunits of the Magura Nappe; Western Flysch Carpathians (Beskid Wyspowy and Gorce Ranges, Poland). Ann. Soc. Geol. Pol., 75: 27-69.

OSZCZYPKO N., MARKOWICZ U. and OSZCZYPKO-CLOWES M. (2011) - The position and age of the Magura sandstones at Klimkówka near Gorlice (Magura Nappe, Polish Outer Carpathians). Grzybowski Found. Spec. Publ., 17: 118-119.

PAUL C.M. (1869) - Die geologischen Verhältnisse des nördlichen Saroser - und Zempliner Comitates. Jb. Geol. R.-A., 19: 1-265.

PAUL K. and TIETZE E. (1879) - Neue Studien in der Sandsteinzone der Karpathen. Jb. Geol. R.-A., 29: 189-304.

POLÁK M., FILO I., HAVRILA M., BEZÁK V., KOHÚT M., KOVÁČ P., VOZÁR J., MELLO J., MAGLAY J., ELEČKO M., OLŠAVSKÝ M., PRISTAŠ J., SIMAN P., BUČEK S., HÓK J., RAKÚS M., LEXA J. and ŠIMON A.L. (2003) - Starohorské vrchy, Bratislava, ŠGÚDŠ.

POTFAJ M. (2003) - Geology of the Slovakian part of the Orava - and overview. Publ. Inst. Geoph., Pol. Acad. Sc., Monographic, 28: 51-56.

POTFAJ M. , MAGLAY J., ŠLEPECKÝ T. and TEŤÁK F. (2002) Geologická mapa regiónu Kysúc. Bratislava, ŠGÚDŠ.

RAJCHEL J. (1990) - Lithostratigraphy of the Upper Paleocene and Eocene sediments from the Skole unit (in Polish with English summary). Zesz. Nauk. AGH, Geologia, 48: 1-100.

RĄCZKOWSKI W., WÓJCIK A., ZIMNA Z., NESCIERUK P., PAUL Z., RYŁKO W., SZYMAKOWSKA F. and YTKO K. (1992) - Mapa geologiczna Polski, A - mapa utworów powierzchniowych, skala 1:200 000, ark. Jasło. Państw. Inst. Geol.

RYŁKO W. (1992) - Lithostratigraphy of the Magura-nappe sediments in the south-east part of the Beskid ywiecki Mts. (External Carpathians) (in Polish with English Wyd. Geol., Warszawa). Biul. Państw. Inst. Geol., 368: 37-63.

RYŁKO W. (2004) - Karpaty. In: Budowa geologiczna Polski, IV (eds. T. Peryt and M. Piwocki): 271-321. Państw. Inst. Geol.

RYŁKO W., YTKO K., RĄCZKOWSKI W. and WÓJCIK A. (1993) Szczegółowa mapa geologiczna Polski, skala 1:50 000, ark. Czadca-Ujsoły. Państw. Inst. Geol. 
SIKORA W. (1971) - Geology of the Magura Nappe between Szymbark Ruski and Nawojowa (in Polish with English summary). Biul. Inst. Geol., 235: 5-121.

SIKORA W. and YTKO K. (1959) - Geology of the Beskid Wysoki Range south of ywiec (Western Carpathians) (in Polish with English summary). Biul. Inst. Geol., 141: 61-204.

ŚLĄCZKA A., KRUGLOV S., GOLONKA J., OSZCZYPKO N. and POPADYUK I. (2006) - The general geology of the Outer Carpathians, Poland, Slovakia, and Ukraine. AAPG Mem., 84: 221-258.

ŚWIDZIŃSKI H. (1947) - Słownik stratygraficzny północnych Karpat fliszowych. Biul. Państw. Inst. Geol., 37: 1-124.

UHLIG V. (1888) - Ergebnisse geologischer Aufnahmen in den westgalizischen Karpathen. Jb. geol. R.-A., 38: 85-264.

WAGNER R., ed. (2008) - Tabela stratygraficzna Polski. Karpaty. Państwowy Instytut Geologiczny.

WAŚKOWSKA A. and GOLONKA J. (2010) - Beloveža Formation in the Rača Unit, Magura Nappe in Hańczowa Mts. (Polish Flysch
Carpathians) and adjacent part of Slovakia and remarks on the Beloveža Formation - Hieroglyphic Beds controversy. Min. Slov., 42: 519-529.

WAŚKOWSKA-OLIWA A. (2008) - Haplophragmoides nauticus Kender, Kaminski \& Jones in the Eocene of the Flysch Carpathians. Grzybowski Found. Spec. Publ., 14: 63-64.

WECŁAWIK S. (1969) - The geological structure of the Magura Nappe between Uście Gorlickie and Tylicz (in Polish with English summary). Pr. Geol., 59: 1-101.

WECŁAWIK S. and WÓJCIK A. (1995) - Szczegółowa mapa geologiczna Polski, skala 1:50 000, ark. Tylicz. Państw. Inst. Geol.

WÓJCIK A., KOPCIOWSKI R., MALATA T., MARCINIEC P. and NEŚCIERUK P. (1996) - Propozycja podziału jednostek litostratygraficznych polskich Karpat zewnętrznych. Przew. 57 Zjazdu Pol. Tow. Geol., Szczyrk, 6-9 czerwca 1996: 209-215. Pol. Tow. Geol., Kraków.

YTKO K. (1962) - Stratigraphy of the Magura Unit in the southwestern part of the Beskid ywiecki (Flysch Carpathians). Bull. Acad. Pol. Sc., Ser. Sc. Geol. Geogr., 10: 167-177. 